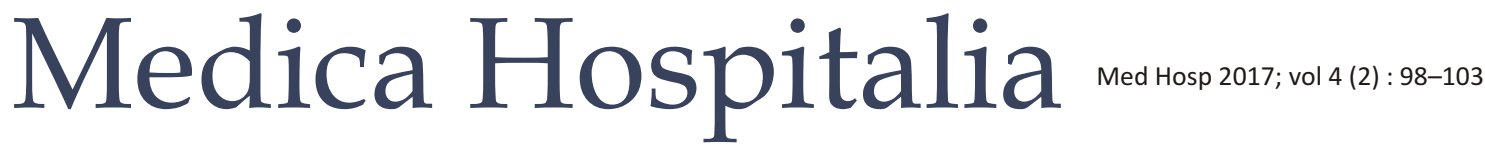

Original Article

\section{Hubungan Dislipidemia dengan Kadar Malondialdehyde (MDA) pada Sindroma Nefrotik Sensitif Steroid Relaps}

\author{
Sylvi Anitasari, Muhammad Heru Muryawan, Galuh Hardaningsih, \\ Kamilah Budi Rahardjani, R. Rochmanadji Widajat
}

Departemen IImu Kesehatan Anak Fakultas Kedokteran Universitas Diponegoro/

RSUP Dr. Kariadi Semarang

\begin{abstract}
Abstrak
Latar belakang : Peroksidasi lipid yang terjadi pada pasien sindroma nefrotik (SN) yang mengalami dilipidemia dapat mempercepat laju dari penyakit ginjal. Stres oksidatif, yang berujung pada pembentukan Spesies Oksigen Reaktif (SOR), turut menyumbang pada proses degeneratif ini. Malondialdehyde (MDA) digunakan sebagai biomarker untuk mengukur stres oksidatif. Penelitian ini bertujuan untuk membuktikan hubungan antara dislipidemia dengan kadar MDA pada SN sensitif steroid relaps.

Metode : Penelitian cross sectional pada anak dengan SN yang memenuhi kriteria inklusi di RSUP Dr. Kariadi Semarang dan RSUD sekitar Semarang periode Februari 2016 sampai Juni 2016. Pengukuran terhadap MDA, kolesterol total, trigliserida, Low Dencity Lipoprotein (LDL) dan High Dencity Lipoprotein (HDL) dinilai saat pasien SN sensitif steroid sedang relaps. Digunakan uji korelasi dan regresi linear untuk mengetahui hubungan antar variabel.

Hasil : Subyek penelitian sebanyak 37 anak yang terdiri 28 (75,7\%) laki-laki dan $9(24,3 \%)$ perempuan. Didapatkan korelasi positif antara MDA dengan kadar kolesterol total $(r=0,386 ; p=0,018)$, trigliserida $(r=0,036 ; p=0,033)$ dan LDL $(r=0,196 ; p=0,045)$. Sementara korelasi negatif didapatkan pada HDL $(r=-0,31 ; p=$ 0,000 ). Pada regresi linear didapatkan kolesterol total memiliki hubungan korelasi terkuat dengan MDA dibandingkan variabel lain $(r=0,386)$. Besarnya angka koefisien determinasi adalah 0,188 atau sebesar $18,8 \%$, dimana kenaikan MDA dapat dijelaskan dengan peningkatan kolesterol total, LDL dan Trigliserida.

Simpulan : Terdapat hubungan antara dislipidemia dengan kadar MDA pada SN sensitif steroid relaps.
\end{abstract}

Kata kunci : Sindroma nefrotik, dislipidemia, malondyaldehyde

\section{The correlation between dyslipidemia and malondialdehyde (MDA) level in relapse phase of sensitive steroid nephrotic syndrome (SSNS)}

\author{
Abstract
}

Background : Lipid peroxidation in Nephrotic Syndrome (NS) patients with dyslipidemia might worsen the kidney disease. Oxidative stress will form Reactive Oxygen Species (ROS) that involve in this degeneration process. Malondyaldehyde (MDA) used as biomarker of the oxidative stress. The objectives of this study was to determine the correlation between dyslipidemia and MDA level in relapse phase of sensitive steroid nephrotic syndrome (SSNS).

Methods: This was a cross sectional study in NS children who match the inclusion criteria in Dr. Kariadi Hospital and another three hospitals from February to June 2016. MDA level, total cholesterol, triglyceride, Low Density Lipoprotein (LDL) and High Density Lipoprotein (HDL) was measured in the relapse phase of SSNS patients. The correlation test and linear regression were used to determine the correlation between variables.

Results : Subjects were 37 children, consists of 28 (75.7\%) males and 9 (24.3\%) females. Positive correlations were found between MDA and total cholesterol $(r=0.386 ; p=0.018)$, triglyceride $(r=$ $0,036 ; p=0,033)$ and LDL $(r=0.196 ; p=0.045)$, meanwhile negative correlation was found in $\mathrm{HDL}(r=-0.31 ; p=0.000)$. From the linear regression, we found that total cholesterol had the strongest correlation to MDA among all variables $(r=0,386)$. The determination coefficient was 0.188 or $18,8 \%$ which explain the rise of MDA was due to total cholesterol, LDL and triglyceride.

Conclusion : There was a correlation between dyslipidemia and MDA level among children in relapse phase SSNS.

Keywords : Nephrotic syndrome, dyslipidemia, malondyaldehyde 


\section{PENDAHULUAN}

Sindroma nefrotik (SN) didefinisikan sebagai keadaan proteinuria berat, hipoalbuminemia, edema dan hiperlipidemia. ${ }^{1,2} \mathrm{SN}$ adalah manifestasi glomerulopati yang paling sering ditemukan pada anak dari keseluruhan kelainan ginjal. Insiden di Indonesia diperkirakan 6 kasus SN per 100.000 anak per tahun dengan rasio laki-laki dan perempuan 2:1.,4 Kelainan histologis pada SN 80\% merupakan SN kelainan minimal, dimana $70 \%$ pasien sindroma nefrotik kelainan minimal terjadi pada usia $<5$ tahun dan peningkatan prevalensi membranous glomerulopathies meningkat seiring kenaikan usia diatas 13 tahun. ${ }^{2,3}$ Secara klinis SN dibedakan menjadi SN kongenital, sensitif steroid dan resisten steroid. $\mathrm{SN}$ sensitif steroid sebagian besar terdiri atas $\mathrm{SN}$ kelainan minimal sementara $\mathrm{SN}$ resisten steroid terdiri atas anak dengan kelainan glomerulus yang lain. ${ }^{3}$

Hiperlipidemia merupakan keadaan dimana terdapat peningkatan kadar lipid dalam darah yaitu trigliserida, kolesterol atau keduanya, sedangkan dislipidemia diartikan sebagai perubahan kadar profil lipid darah dapat meningkat (kolesterol total, trigliserida, LDL) atau menurun HDL. ${ }^{5}$ Hiperlipidemia hampir selalu terjadi pada SN kelainan minimal dengan 95\% dari keseluruhan anak mempunyai kadar kolesterol serum $>250 \mathrm{mg} / \mathrm{dl}^{6}{ }^{6,7,8}$

Penelitian menunjukkan bahwa hiperkolesterolemia mempercepat laju dari penyakit ginjal. Samuelsson dkk menunjukkan korelasi yang kuat diantara lipoprotein yang mengandung apo-B kaya akan trigliserida dan laju dari keadaan penyakit ginjal kronik pada pasien nondiabetik. ${ }^{9}$ Di sisi lain terdapat pula penelitian Kantosh dkk yang mengatakan bahwa hipoalbuminemia menyebabkan penurunan tekanan onkotik dalam serum, yang selanjutnya akan merangsang sintesis albumin dan protein lainnya oleh hepar, termasuk apolipoprotein. ${ }^{10}$

Sindroma nefrotik adalah akibat dari ketidakseimbangan antara oksidan dan antioksidan. Adanya hubungan antar hiperlipidemia dan stres oksidatif pada patogenesis kerusakan ginjal terlihat pada hiperlipidemia meningkatkan infiltrasi glomerulus dan tubulointerstitial dan meningkatkan glomerulosklerosis pada sindroma nefrotik. Stres oksidatif, yang berujung pada pembentukan Reactive Oxigent Species/ Spesies Oksigen Reaktif (SOR), secara signifikan turut menyumbang pada proses degeneratif yang kronik ini. ${ }^{1,11}$ Penelitian Bafna dkk menyimpulkan bahwa stres oksidatif meningkat pada pasien dengan sindroma nefrotik dan lupus nefritis karena hiperhomosisteinemia, hiperlipoproteinemia dan hipoproteinemia. ${ }^{12}$

SOR akan mendegradasi polyunsaturated lipids membentuk Malondialdehyde (MDA) yang digunakan sebagai biomarker untuk mengukur stres oksidatif. MDA menggambarkan interaksi antara molekul oksigen dengan asam lemak, sedangkan membran sel memiliki kadar asam lemak yang tinggi yang mengakibatkan kerentanan terhadap reaksi oksidasi oleh spesies oksigen reaktif. Oleh karena sulit mengidentifikasi kadar radikal bebas oksigen, lipid peroksidase sering digunakan sebagai indeks terhadap cedera sel akibat radikal bebas. ${ }^{13}$ Dikatakan pada penelitian Ghodake dkk bahwa hiperlipidemia, terutama hiperkolesterolemia dapat menyebabkan peningkatan reaksi peroksidasi lipid. Kadar MDA meningkat secara signifikan pada SN relaps dibandingkan control, pada saat yang sama didapatkan penurunan signifikan nitric oxide, aktivitas eritrosite-super oxide dismutase, kadar vitamin $\mathrm{C}$, albumin dan kapasitas total antioksidan pada pasien SN. ${ }^{14,15}$

Penelitian ini bertujuan untuk membuktikan hubungan antara dislipidemia dengan kadar MDA pada SN sensitif steroid relaps.

\section{METODE}

Penelitian dilakukan bangsal anak rawat inap dan rawat jalan RSUP Dr. Kariadi Semarang dan RSUD sekitarnya pada bulan Februari - Juni 2016. Penelitian adalah penelitian observasional dengan desain cross sectional. Subyek penelitian adalah anak usia 5-13 tahun yang menderita $\mathrm{SN}$ sensitif steroid relaps di bangsal rawat inap dan poliklinik rawat jalan RSUP Dr. Kariadi Semarang dan RSUD yang berada di sekitar Semarang yang memenuhi kriteria inklusi dan eksklusi. Subyek penelitian untuk hubungan SN dan trigliseride 37 orang dan dipilih menggunakan consecutive sampling. Pengukuran konsentrasi kolesterol total, trigliserida, LDL dan LDL menggunakan alat Dimerson RXL. Sementara kadar Malondialdehyde (MDA) diperiksa menggunakan metoda Hunter dengan pemeriksaan spektrofotometri panjang gelombang $532 \mathrm{~nm}$, diukur dengan mengukur kadar Thio Barbituric Acid Reactive Substance (TBARS). Apabila didapatkan sebaran data normal maka uji hipotesis menggunakan Pearson dan apabila sebaran data tidak normal maka digunakan uji alternatifnya yaitu uji Spearman (non parametrik) dan dilanjutkan uji multivariat regresi logistik. Batas kemaknaan adalah $p \leq 0,05$ dengan interval kepercayaan $95 \%$. Analisa data dilakukan dengan program SPSS for Windows versi 15.0 (SPSS Inc, USA).

Sebelum penelitian dilakukan, prosedur penelitian telah dimintakan ethical clearance dari Komisi Etik Penelitian Kesehatan/Kedokteran FK UNDIP/ RSUP Dr. Kariadi Semarang. Setiap pasien SN yang memenuhi kriteria subyek penelitian akan dimintakan persetujuan orang tua/wali dengan menggunakan informed consent tertulis. 


\begin{tabular}{|lccc|}
\hline $\begin{array}{l}\text { TABEL 1 } \\
\text { Karakteristik subyek penelitian }\end{array}$ & $\begin{array}{c}\text { N (\%) } \\
\text { N = 37 }\end{array}$ & Rerata & $\begin{array}{c}\text { Median } \\
\text { (Min - Maks) }\end{array}$ \\
\hline $\begin{array}{l}\text { Jenis kelamin } \\
\text { Laki-laki }\end{array}$ & $28(75,7 \%)$ & & \\
$\quad$ Perempuan & $9(24,3 \%)$ & & \\
Derajat proteinuria & $1(2,7 \%)$ & & \\
$\quad<300$ & $36(97,3 \%)$ & & \\
$\quad>300$ & & $1,72 \pm 0,54$ & \\
Albumin & & 445,12 tahun) \\
Usia & & $338,35 \pm 118$ & \\
Kolesterol total & & $299,2 \pm 74,9$ & \\
Trigliserida & & & \\
LDL & & $7,54 \pm 4,3$ & \\
HDL & & & \\
MDA & & & \\
\hline
\end{tabular}

LDL: Low Dencity Lipoprotein; HDL: High Dencity Lipoprotein; MDA: Malondialdehyde

\section{HASIL}

Dari ke 37 orang subyek penelitian tersebut, jenis kelamin terbanyak adalah laki-laki yaitu 28 orang $(75,7 \%)$, dengan usia termuda 5 tahun, tertua 12 tahun, 1 orang yang proteinuria $<300(2,7 \%)$, rerata kadar albumin $1,72 \pm$ 0,54 , dengan asupan kalori rata-rata 3 hari terakhir adalah 1500 dengan nilai tertinggi 2300 dan terendah 1200. Rerata kadar kolesterol total 445,8 $\pm 85,6$. Rerata kadar trigliserida 338,35 \pm 118 . Rerata kadar LDL 299,2 $\pm 74,9$. Kadar HDL terendah 12, tertinggi 123 dengan median 40. Rerata kadar MDA 7,54 $\pm 4,3$.

Tabel 2 menunjukkan bahwa terdapat korelasi yang bermakna dan arah korelasi positif antara MDA dengan kadar kolesterol total $(\mathrm{r}=0,386 ; p=0,018)$ dengan kekuatan korelasi yang lemah, trigliserida $(\mathrm{r}=0,036 ; p=0,033)$ dengan kekuatan korelasi yang sangat lemah, LDL $(r=0,196 ; p=0,045)$ kekuatan korelasi yang sangat lemah. Sementara korelasi negatif didapatkan pada HDL $(\mathrm{r}=-0,31 ; p=0,000)$ kekuatan korelasi yang sangat lemah.

Dengan demikian dapat dikatakan pada subyek dengan kadar koleterol total, trigliserida dan LDL yang tinggi akan memiliki kadar MDA yang tinggi. Sementara subyek dengan kadar HDL rendah akan memiliki kadar MDA yang tinggi.

Pada tabel 3, didapatkan hubungan yang bermakna antara kolesterol total $(p=0,009), \operatorname{LDL}(p=0,022)$ dan trigliserida $(p=0,017)$ terhadap MDA, tidak terdapat hubungan yang bermakna antara HDL dan MDA $(p=0,308)$. Kadar kolesterol total memiliki hubungan korelasi terkuat dengan MDA dibandingkan variabel lain. Besarnya angka koefisien determinasi adalah 0,188 atau sebesar 18,8\%, dimana kenaikan MDA dapat dijelaskan dengan peningkatan kolesterol total, LDL dan Trigliserida. Besarnya pengaruh kolesterol total, LDL dan Trigliserida terhadap kadar MDA adalah 18,8\%. Sementara itu, $81,2 \%$ dipengaruhi oleh faktor lainnya diluar model regresi ini.

\section{PEMBAHASAN}

Penelitian ini adalah penelitian observasional dengan desain cross sectional. Selama periode penelitian pada bulan Februari - Juni 2016, didapatkan 37 subyek penelitian yaitu anak usia $5-13$ tahun dengan $\mathrm{SN}$ sensitif steroid relaps. Pemilihan usia termuda 5 tahun adalah karena $70 \%$ pasien sindroma nefrotik kelainan minimal terjadi pada usia $<5$ tahun. ${ }^{3}$ Hiperlipidemia terjadi pada 95\% pasien anak dengan SN kelainan minimal dimana kolesterol mencapai $>250 \mathrm{mg} / \mathrm{dl}^{6}{ }^{6}$ Pada penelitian sebelumnya di Semarang tentang suplementasi ikan gabus terhadap penderita SN didapatkan rerata usia subyek adalah 5 tahun. ${ }^{17}$ Sementara usia tertua 13 tahun karena faktor peningkatan prevalensi membranous glomerulopathies meningkat seiring kenaikan usia diatas 
TABEEL 2

Korelasi antara kolesterol total, trigliserida, LDL dan HDL dengan MDA

\begin{tabular}{lcc} 
Variabel & Koefisien Korelasi & $\boldsymbol{p}$ \\
\hline Kolesterol total dengan MDA & 0,386 & 0,018 \\
Trigliserida dengan MDA & 0,036 & 0,033 \\
LDL dengan MDA & 0,196 & 0,045 \\
HDL dengan MDA & $-0,31$ & 0,000
\end{tabular}

LDL: Low Dencity Lipoprotein; HDL: High Dencity Lipoprotein; MDA: Malondialdehyde

\section{TABEL 3}

Regresi linear antara kadar kolesterol total, HDL, LDL dan Trigliserida dengan MDA

\begin{tabular}{lcr} 
Variabel & Pearson Korelasi & $\boldsymbol{p}$ \\
\hline Kolesterol Total & 0,386 & 0,009 \\
LDL & 0,196 & 0,022 \\
Trigliserida & 0,036 & 0,017 \\
HDL & $-0,085$ & 0,308
\end{tabular}

LDL: Low Dencity Lipoprotein; HDL: High Dencity Lipoprotein

13 tahun. ${ }^{2,3}$ Hiperlipidemia hanya terjadi pada $68 \%$ anak dengan SN tipe membranous glomerulopathies. ${ }^{6}$

Insiden SN diperkirakan mencapai 6 kasus tiap 100.000 anak usia kurang dari 14 tahun dan rasio laki-laki berbanding perempuan adalah 2:1.3,4 Pada penelitian ini, lebih banyak subyek berjenis kelamin laki-laki 28 orang (75,7\%), dibandingkan perempuan yaitu 9 orang (24,3\%). Sebuah penelitian di Kairo, Mesir, mendapatkan rasio penderita SN antara laki-laki dan perempuan adalah 2:1. ${ }^{18}$ Sementara menurut sebuah penelitian di Yogyakarta terhadap 129 anak dengan SN primer, didapatkan rasio laki-laki dan perempuan sebesar 3:1. ${ }^{19}$

Proteinuria sebagai konsekuensi adanya kenaikan permeabilitas glomerulus merupakan kelainan utama pada SN yang menimbulkan berbagai komplikasi seperti hipoalbuminemia, edema dan hiperkolesterolemia. Hampir seluruh subyek mengalami proteinuria $>300$ $\mathrm{mg} / \mathrm{dl}(97,3 \%)$, sementara rerata kadar albumin 1,72 \pm $0,54 \mathrm{gr} /$ dl. Pada penelitian di Kairo didapatkan rerata kadar albumin fase akut SN kelainan minimal sebesar 1,82 $\pm 0,55 \mathrm{gr} / \mathrm{dl}$ dan SN bukan kelainan minimal sebesar $1,31 \pm 0,2 \mathrm{gr} / \mathrm{dl}$. Terjadinya dislipidemia pada $\mathrm{SN}$ umumnya berhubungan dengan proteinuria berat yang juga merupakan fitur integral dari SN. ${ }^{8}$ Namun demikian hingga saat ini masih belum jelas dislipidemia merupakan konsekuensi langsung dari proteinuria ataukah akibat sekunder dari efek proteinuria seperti penurunan tekanan onkotik dan hipoalbuminemia. ${ }^{20}$
Dislipidemia pada SN dihubungkan dengan reaksi oksidatif yang menyebabkan ketidakseimbangan antara prooksidan dan antioksidan. Penurunan antioksidan ini juga menyebabkan penurunan kemampuan menetralisir radikal superoksida yang dihasilkan oleh proses oksidasi LDL. Pada penelitian ini didapatkan kenaikan kolesterol total, LDL dan trigliserida pada semua subyek penelitian, serta penurunan HDL. Menurut penelitian di Mesir pada anak SN sensitif steroid fase relaps didapatkan kadar kolesterol total lebih tinggi $(422,33 \pm 50,7)$, kadar trigliserida yang lebih tinggi $(313,66 \pm 26,95 \mathrm{mg} / \mathrm{dl})$, LDL lebih tinggi $(143,86 \pm 10,88)$ dan HDL lebih rendah $(30,24 \pm 6,33)$ bila dibandingkan fase remisi. Peningkatan kolesterol total berhubungan dengan penurunan mevalonat karena SN, juga peningkatan HMG-CoA reductase sehingga meningkatkan sintesis kolesterol oleh hepar. Peningkatan LDL melalui dua mekanisme yaitu penurunan katabolisme LDL dan peningkatan aktifitas cholesterol ester transfer protein yang meningkatkan sintesis LDL. Peningkatan kadar trigliserida karena penurunan katabolisme lipoprotein. Sementara itu, penurunan HDL dikarenakan ekskresinya yang berlebih kemudian digunakan untuk antioksidan yang menghambat modifikasi oksidatif LDL dan untuk antiinflamasi. ${ }^{20}$

Malondialdehyde (MDA) yang digunakan sebagai biomarker untuk mengukur stres oksidatif. Rerata kadar 
MDA yang didapatkan pada penelitian ini adalah 7,54 \pm $4,3 \mu \mathrm{mol} / \mathrm{L}$. Pada penelitian di India didapatkan kadar MDA fase relaps adalah 4,94 $\pm 2,12 \mu \mathrm{mol} / \mathrm{L}$ dan saat remisi sebesar 9,37 $\pm 2,68 \mu \mathrm{mol} / \mathrm{L}$. Pada penelitian di India didapatkan kadar MDA pada SN serangan pertama sebesar 1,4 $\pm 0,4 \mu \mathrm{mol} / \mathrm{L}$, SN relaps sering $1,4 \pm 0,5 \mu \mathrm{mol} / \mathrm{L}$, $\mathrm{SN}$ relaps jarang $1,6 \pm 0,4 \mu \mathrm{mol} / \mathrm{L}$, dan fase remisi median $0,9 \mu \mathrm{mol} / \mathrm{L}(0,7-1,4) \cdot{ }^{21}$ Peningkatan kadar MDA ini menunjukkan peningkatan stres oksidatif pada pasien denganSN.

Hiperlipidemia, terutama hiperkolesterolemia dapat menyebabkan peningkatan peroksidasi lipid. Pada penelitian ini, hubungan antara kadar kolesterol total dan MDA didapatkan korelasi yang bermakna $(p<0,05)$, nilai korelasi 0,386 dengan arah korelasi yang positif dan kekuatan korelasi yang lemah. Pada hubungan antara trigliserida dan MDA didapatkan korelasi yang bermakna $(p<0,05)$, nilai korelasi 0,036 dengan arah korelasi yang positif dan kekuatan korelasi sangat lemah. Pada hubungan LDL dan MDA didapatkan korelasi yang bermakna $(p<0,05)$, nilai korelasi 0,196 dengan arah korelasi yang positif dan kekuatan korelasi sangat lemah. Pada penelitian di India terhadap 30 anak dengan SN dan 30 kontrol, mendapatkan hasil kolesterol meningkat secara signifikan pada kelompok perlakuan, demikian pula dengan kadar MDA. Peningkatan kerusakan oksidatif mungkin adalah konsekuensi jangka panjang dari hiperkolesterolemia. Lipid adalah target molekul untuk radikal bebas sehingga hiperlipidemia dapat meningkatkan radikal bebas yang dalam hal ini diwakili oleh kadar MDA. ${ }^{14}$

Di sisi lain, pada hubungan antara HDL dan MDA, didapatkan korelasi yang bermakna $(p<0,05)$, nilai korelasi $-0,031$ dengan arah korelasi yang negatif dan kekuatan korelasi sangat lemah. Hal ini berhubungan dengan fungsi HDL sebagai antioksidan yang akan digunakan untuk menekan modifikasi oksidatif yang terjadi pada pasien $\mathrm{SN} .{ }^{20}$

Pada analisis regresi antara berbagai variabel hiperlipidemia dan MDA pada penelitian ini didapatkan korelasi yang signifikan antara kolesterol total, LDL dan trigliserida terhadap MDA dengan arah korelasi positif, sementara untuk HDL tidak terdapat hubungan yang signifikan. Besarnya koefisien determinasi adalah $18,8 \%$, sehingga kemungkinan $81,2 \%$ dipengaruhi oleh faktor lainnya. Hal ini menunjukkan bahwa pada pasien SN terdapat kenaikan stres oksidatif yang berhubungan dengan dislipidemia. Pada penelitian di India tentang profil lipid pada pasien SN dan nefritis lupus, didapatkan hasil koefisien korelasi antara lipoprotein dan MDA $+0,90(p<0,001)$ pada pasien nefritis lupus. ${ }^{11}$ Sementara sebuah penelitian di Mesir terhadap SN sensitif steroid mendapatkan adanya peningkatan MDA, LDL teroksidasi, LDL, kolesterol total, trigliserida, apolipoprotein A dan B serta penurunan albumin, aktifitas glutation peroksidase, vitamin C, vitamin E dan
HDL. Didapatkan pula hubungan yang kuat dan signifikan antara status oksidan/antioksidan dan dislipidemia pada pasien SN sensitif steroid terutama yang sedang relaps. ${ }^{13}$

Keterbatasan pada penelitian ini adalah tidak adanya pemeriksaan histopatologi pada subyek penelitian, hanya terbatas pada SN sensitif steroid relaps dan tidak ada kontrol. Selain itu hanya dilakukan pemeriksaan kadar MDA yang mewakili oksidan tanpa ada pemeriksaan antioksidan.

\section{SIMPULAN}

Terdapat hubungan antara dislipidemia dalam hal ini hiperkolesterolemia total, hipertrigliseridemia, peningkatan kadar LDL dan penurunan kadar HDL dengan kadar MDA pada SN sensitif steroid relaps. Disarankan untuk dilakukan penelitian hubungan dislipidemia dengan MDA pada jenis SN yang lain, melibatkan kontrol, variabel antioksidan dan pemeriksaan MDA menggunakan metode High Performance Liqiud Chromatography (HPLC) yang lebih akurat.

\section{DAFTAR PUSTAKA}

1. Dwivedi J, Sarkar PD. Study of oxidative stres, homocysteine, copper \& zinc in nephrotic syndrome : therapy with antioxidants, minerals and B-complex vitamins. J Biochem Tech. 2009; $1: 104-7$

2. Noer MS. SN Idiopatik. In: Noer MS, (ed.). Kompendium Nefrologi Anak. Jakarta: Ikatan Dokter Anak Indonesia, 2011, p. $72-4$

3. Alatas H, Tambunan T, Trihono P, Pardede SO. Sindroma Nefrotik. In: Wirya W, (ed.). Buku ajar Nefrologi Anak. Jakarta: Ikatan Dokter Anak Indonesia, 2010, p. 381-4.

4. Alatas H, Tambunan T, Trihono P, Pardede SO. Konsensus tatalaksana sindrom nefrotik idiopatik pada anak. Jakarta: Unit kerja koordinasi nefrologi Ikatan Dokter Anak Indonesia, 2005, p.1-17

5. Ahlian A. Perbedaan profil lipid darah pada asupan lemak normal dan lemak tinggi anak dengan obesitas usia 6-7 tahun. Departemen Ilmu Kesehatan Anak. Semarang: Diponegoro, 2005, p. 1-85.

6. Thabet MA, Salcedo RJ, Chan JC. Hyperlipidemia in childhood nephrotic syndrome. Pediatr Nephrol. 2003; 7:559-66

7. Lawang SA, Rauf S, Lisal JS, Albar H, Daud D. Plasma lipid as risk factors in relapsing nephrotic syndrome. Paediatrica Indonesiana. 2008;48:322-5

8. Trevisan R, Dodesini A, Lepore G. Lipids and renal disease. J Am Soc Nephrol. 2008; 7:145-7

9. Samuelsson O, Mulec H, Knight-Gibson C, Attman PO, Kron B, Larsson B, Weiss L, et al. Lipoprotein abnormality are associated with increased rate of progression of human chronic renal insufficiency. Nephrol Dial Transplant. 2007;12: 1908-15

10. Kantossh MM, Naiem AM, El-Sayad M, Nashat M. Dyslipidemia and lipid peroxidation in type 1 diabetic children with good glycemic control: response to antioxidant therapy. Alexandria Journal of Pediatric. 2012;16:357-64

11. Dwivedi J, Sarkar PD. Study of homocysteine, lipoprotein (a), lipid profile with oxidative stres in nephrotic syndrome and 
lupus nephritis. RJPBCS. 2010;1:670-9.

12. Bafna A, Sarkar PD, Bafna S. Study of homocysteine, total antioxidant capacity, lipoprotein (a) and minerals in steroid sensitive nephrotic syndrome. Int J Biol Med Res. 2011; 2: 536-8.

13. Nezhad ST, Momeni B, Basiratnia M. Glomerular malondialdehyde levels in patients with focal and segmental glomeruloschlerosis and minimal change disease. Saudi J Kidney Dis Transpl. 2010;21:889-91.

14. Ghodake SR, Suryakar AN, Ankush RD, Katkam RV, Saikh K, Katta AV. Role of free radicals and antioxidant status in childhood nephrotic syndrome. Indian J Nephrol. 2011; 21: 37-40.

15. Ghodake SR, Suryakar AN, Ankush RD, Katkam RV, Saikh K, Katta AV. Role of reactive oxygen spesies in pathogenesis of nephrotic syndrome. Indian Journal of Clinical Biochemistry. 2010; 25: 82-5.

16. Bakr A, Hasan SA, Shoker M, Zaki M, Hassan R. Oxidant stres in primary nephrotic syndrome: does it modulate the response to corticosteroid. Pediatr Nephrol. 2009; 24: 2375-80.
17. Hardaningsih G. Pengaruh suplementasi kapsil ekstrak ikan gabus terhadap parameter klinis dan laboratorium pada sindroma nefrotik yang mendapatkan infus human albumin. Fakultas Kedokteran Semarang: Universitas Diponegoro, 2012.

18. Shouman M, Abdallah N, Tablawy NE and Rashed L. Biochemical markers of endothelial dysfunction in pediatric nephrotic syndrome. Arch med schi. 2009; 5: 415-21.

19. Damanik MP. Clinical feature of nephrotic syndrome in children. Pediatrica Indonesiana. 1997:14-9.

20. Zilleruelo G, Hsia SL, Freundlich M, Gorman HM, Strauss J. Persistence of serum lipid abnormalities in children with idiopathic nephrotic syndrome. J Pediatr. 2007; 104: 61-4.

21. Suys B, deBeek LO, Rooman R, Kransfeld S, Heuten H, Goovaerts I, et al. Impact of oxidative stres on the endothelial dysfunction of children and adolescents with type 1 diabeles melitus: protection by superoxide dismutase. Pediatric Research. 2007; 62: 456-61. 